\title{
KEMAMPUAN BERPIKIR TINGKAT TINGGI SISWA KELAS XI DALAM PEMBELAJARAN TRIGONOMETRI BERBASIS MASALAH DI SMA NEGERI 18 PALEMBANG
}

\author{
Etika Prasetyani, Yusuf Hartono, dan Ely Susanti \\ etikaajeng@gmail.com \\ Pendidikan Matematika - FKIP Universitas Sriwijaya \\ 2016
}

\begin{abstract}
Abstrak
Penelitian ini bertujuan untuk mendeskripsikan tentang kemampuan berpikir tingkat tinggi siswa pada pembelajaran matematika berbasis masalah. Penelitian ini merupakan jenis penelitian deskriptif dengan subjek penelitian yaitu siswa kelas XI MIPA 1 SMA Negeri 18 Palembang yang berjumlah 30 orang. Proses pembelajaran berlangsung sesuai dengan karakteristik dan langkahlangkah pembelajaran berbasis masalah. Teknik pengumpulan data yang digunakan adalah tes tertulis yang terdiri atas tiga soal dan wawancara untuk memperoleh data tambahan. Berdasarkan hasil penelitian, diperoleh hasil kemampuan berpikir tingkat tinggi siswa dalam pembelajaran matematika berbasis masalah di kelas XI MIPA 1 SMAN 18 Palembang adalah terkategori cukup dengan rincian sebagai berikut: persentase siswa yang memiliki kemampuan berpikir tingkat tinggi sangat baik adalah sebesar 16,667\%. Selanjutnya, 26,667\% memiliki kemampuan berpikir tingkat tinggi dengan kategori baik; 30,000\% memiliki kemampuan berpikir tingkat tinggi terkategori cukup; 26,667\% memiliki kemampuan berpikir tingkat tinggi terkategori kurang; dan tidak ada yang memiliki kemampuan berpikir tingkat tinggi dengan kategori sangat kurang. Indikator menganalisis memiliki persentase kemunculan tertinggi yaitu sebesar 72,500\%. Kemudian, kemunculan pada indikator mengevaluasi adalah sebesar $70,000 \%$, dan indikator dengan persentase kemunculan terendah adalah mengkreasi yaitu sebesar 35,417\%.

Kata kunci: kemampuan berpikir tingkat tinggi, pembelajaran trigonometri, berbasis masalah
\end{abstract}

\begin{abstract}
This study is descriptive research aiming to describe students' higher order thinking skills in mathematics problem-based learning. Total of 30 students of class XI Mathematics 1 SMA Negeri 18 Palembang were selected as research subjects. The learning process was done in accordance with the characteristics and steps of problem-based learning. Data were collected through written test consisting of three questions and interviews to obtain additional data. The results of the study shows that students' higher order thinking skills in mathematics problem-based learning in class XI MIPA 1 SMAN 18 Palembang is categorized enough: 16,67\% of students are categorized excellent; $26.667 \%$ are categorized good; $30.00 \%$ are categorized enough; $26.667 \%$ are categorized low; and no one are in very poor category. The most frequent indicator of higher order thinking skills appeared, $72.50 \%$, is analyzing and then $70.00 \%$ evaluating. Meanwhile, the least frequent indicator appeared is creating, $35.417 \%$.
\end{abstract}

Keywords: higher order thinking skills, trigonometry problem based learning 
JURNAL GANTANG Pendidikan Matematika FKIP - UMRAH

Vol. 1 No. 1, Agustus 2016, p-ISSN. 2503-0671, e-ISSN. 2548-5547

\section{Pendahuluan}

Pendidikan berperan penting dalam menyiapkan sumber daya manusia untuk pembangunan suatu bangsa. Menurut hasil laporan lembaga internasional mengenai masalah pendidikan, indeks pendidikan Indonesia berada pada urutan ke 110 dari 180 negara di dunia. Selain itu, berdasarkan data dari Education For All (EFA) Global Monitoring Report pada tahun 2011 yang dikeluarkan oleh UNESCO, indeks pembangunan pendidikan Indonesia berada pada peringkat ke-69 dari 127. Salah satu penyebab rendahnya prestasi siswa ini dikarenakan lemahnya proses pembelajaran di Indonesia. Dalam proses pembelajaran, siswa kurang didorong untuk mengembangkan kemampuan berpikir (Permanasari, 2013). Namun, banyak pembelajaran matematika di kelas yang belum memanfaatkan keterampilan berpikir tingkat tinggi siswa (Luthfiana, 2013). Amalia (2013) juga mengemukakan bahwa salah satu kemampuan berpikir yang penting dikuasai oleh siswa adalah kemampuan berpikir tingkat tinggi.

Akan tetapi, seringkali kemampuan berpikir tingkat tinggi tersebut masih belum tercapai dengan baik, contohnya di SMA Negeri 18 Palembang. Dari hasil survei dan wawancara di SMA Negeri 18 Palembang, diperoleh informasi bahwa Kriteria Ketuntasan Minimal (KKM) untuk pelajaran matematika adalah 75 , dimana $100 \%$ siswa kelas XI MIPA 1 mendapatkan kategori tuntas. Dari soal-soal ulangan yang diberikan, terlihat bahwa soal tersebut masih jarang melatih kemampuan berpikir tingkat tinggi siswa. Ketika diberikan soal dengan level yang lebih tinggi, dari jawaban siswa terlihat bahwa kebanyakan siswa masih belum mampu menghubungkan, memanipulasi, dan mentransformasi pengetahuan serta pengalaman yang sudah dimiliki untuk berpikir kritis dan kreatif dalam upaya menentukan keputusan dan memecahkan masalah pada situasi baru. Shadiq (2007) mengatakan bahwa karakteristik pembelajaran matematika saat ini adalah lebih fokus pada kemampuan prosedural, komunikasi satu arah, pengaturan kelas monoton, low order thinking skill, bergantung pada buku paket, lebih dominan soal rutin dan pertanyaan tingkat rendah.

Berdasarkan uraian di atas, diperoleh kesimpulan bahwa persiapan guru mempengaruhi kemampuan berpikir siswa. Oleh karenanya, guru dituntut dapat memilih pendekatan atau model pembelajaran yang tidak hanya dapat memacu semangat setiap siswa untuk aktif terlibat dalam pengalaman belajarnya, tetapi juga yang dapat mengakomodasi proses berpikir, baik yang melibatkan pengembangan berpikir kritis maupun kreatif. Salah satu alternatif model pembelajaran yang dapat memungkinkan untuk mengembangkan kemampuan berpikir tingkat tinggi adalah pembelajaran berbasis masalah (PBM).

Kardi dan Nur (2000) mengatakan bahwa pengajaran berlandaskan permasalahan merupakan strategi yang sangat efektif untuk mengajarkan proses-proses berpikir tingkat tinggi. Berdasarkan penelitian yang telah dilakukan oleh Ulfa (2013) mengenai pengaruh strategi pembelajaran berbasis masalah terhadap kemampuan berpikir tingkat tinggi dan keterampilan proses sains mahasiswa STIPAP LPP Medan, terdapat pengaruh antara strategi pembelajaran berbasis masalah terhadap kemampuan berpikir tingkat tinggi, yakni kemampuan berpikir tingkat tinggi mahasiswa yang dibelajarkan dengan SPBM signifikan lebih tinggi dibandingkan dengan pembelajaran tradisional sebesar $13,83 \%$. Oleh sebab itu peneliti tertarik untuk mendeskripsikan kemampuan berpikir tingkat tinggi siswa kelas XI dalam pembelajaran matematika berbasis masalah di SMAN 18 Palembang.

Taksonomi Bloom dianggap merupakan dasar bagi berpikir tingkat tinggi. Pemikiran ini didasarkan bahwa beberapa jenis pembelajaran memerlukan proses kognisi yang lebih daripada yang lain, tetapi memiliki manfaat yang lebih umum. Pada taksonomi Bloom, terdapat enam jenjang yang tersusun mulai dari kemampuan berpikir tingkat rendah (lower order thinking 
skill) menuju pada kemampuan berpikir tingkat tinggi (higher order thinking skill).

Kemampuan berpikir tingkat rendah meliputi ranah pengetahuan, pemahaman, dan aplikasi/penerapan. Sedangkan kemampuan berpikir tingkat tinggi meliputi ranah menganalisis, mengevaluasi, dan mengkreasi. Adapun indikator dalam penelitian ini adalah menganalisis, mengevaluasi, dan mengkreasi. Adapun indikator kemampuan berpikir tingkat tinggi yang digunakan dalam penelitian ini adalah sebagai berikut:

1. Menganalisis

Deskriptor: Mampu memeriksa dan mengurai informasi, memformulasikan masalah, serta memberikan langkah penyelesaian dengan tepat.

2. Mengevaluasi

Deskriptor: Mampu menilai, menyangkal, ataupun mendukung suatu gagasan dan memberikan alasan yang mampu memperkuat jawaban yang diperoleh.

3. Mengkreasi

Deskriptor: Mampu merancang suatu cara untuk menyelesaikan masalah atau memadukan informasi menjadi strategi yang tepat.

Beberapa penelitian mengenai kemampuan berpikir tingkat tinggi telah pernah dilaksanakan. Dari penelitian Raudenbush, et.al disimpulkan bahwa pemahaman guru tentang kemampuan berpikir tingkat tinggi yang baik memberikan pengaruh yang signifikan untuk persiapan guru dalam mengajarkan materi pengembangan berpikir tingkat tinggi bagi siswanya. Lewy, Zulkardi, dan Aisyah (2009) melalui penelitiannya menyarankan agar guru menggunakan soal-soal berlevel kemampuan berpikir tingkat tinggi karena soal-soal tersebut memiliki efek potemsial terhadap hasil tes kemampuan berpikir tingkat tinggi. Novianti (2014) dalam penelitiannya mengemukakan bahwa beberapa hambatan siswa dalam menyelesaikan soal berkemampuan tingkat tinggi adalah kurang gigihnya siswa dan ketidakcermatan siswa dalam berpikir. Novianti
(2014) juga menyarankan agar guru dapat menggunakan soal-soal kemampuan berpikir tingkat tinggi dalam pembelajaran matematika. Sastrawati (2011) dalam penelitiannya menyimpulkan bahwa penerapan penggunaan model PBL memberi pengaruh terhadap keterampilan berpikir tingkat tinggi siswa. Selain itu, melalui Ulfa (2013) juga didapatkan hasil bahwa kemampuan berpikir tingkat tinggi mahasiswa yang dibelajarkan dengan SPBM signifikan lebih tinggi dibandingkan dengan pembelajaran tradisional sebesar $13,83 \%$.

Menurut Khotimah (2011), PBM merupakan suatu pembelajaran inovatif yang digunakan untuk melatih kemampuan siswa memecahkan masalah melalui pengalamanpengalaman nyata. PBM merupakan inovasi dalam pembelajaran karena dalam PBM kemampuan berpikir siswa betul-betul dioptimalkan melalui proses kerja kelompok atau tim yang sistematis, sehingga siswa dapat memberdayakan, mengasah, menguji, dan mengembangkan kemampuan berpikirnya secara berkesinambungan. Pada penelitian ini, terdapat empat langkah pelaksanaan PBM, yaitu: orientasi masalah, memahami masalah, menentukan dan menerapkan strategi penyelesaian, dan meninjau ulang proses dan hasil.

\section{Metode Penelitian}

Penelitian ini merupakan penelitian deskriptif. Dalam penelitian ini, peneliti akan mendeskripsikan kemampuan berpikir tingkat tinggi siswa kelas XI dalam pembelajaran matematika menggunakan strategi pembelajaran berbasis masalah di SMA Negeri 18 Palembang.

Variabel dalam penelitian ini adalah kemampuan berpikir tingkat tinggi siswa kelas XI dalam pembelajaran trigonometri.

Kemampuan berpikir tingkat tinggi siswa dalam penelitian ini adalah kemampuan siswa untuk menganalisis, mengevaluasi, dan mengkreasi. Kemampuan tersebut dinilai dengan menggunakan skor yang diperoleh siswa melalui soal tes berpikir tingkat tinggi. 
JURNAL GANTANG Pendidikan Matematika FKIP - UMRAH

Vol. 1 No. 1, Agustus 2016, p-ISSN. 2503-0671, e-ISSN. 2548-5547

Subjek dalam penelitian ini adalah siswa kelas XI MIPA 1 SMA Negeri 18 Palembang yang berjumlah 30 siswa.

Prosedur dalam penelitian ini terdiri atas tiga tahapan, yaitu tahap persiapan, tahap pelaksanaan kegiatan, dan tahap pengumpulan data.

Dalam penelitian ini, data dikumpulkan melalui tes tertulis dan wawancara.

Tes yang diberikan merupakan tes tertulis bentuk uraian. Tes ini terdiri dari tiga buah soal yang harus dijawab siswa mengenai kompetensi dasar dan indikator kemampuan berpikir tingkat tinggi siswa terkait materi rumusrumus segitiga pada trigonometri. Tes ini dikerjakan siswa secara individu.

Wawancara dilakukan untuk memperoleh data tambahan atau informasi lebih lanjut mengenai jawaban dan alasan siswa dalam menjawab soal serta kesulitannya dalam menjawab soal. Subjek wawancara adalah masing-masing satu orang siswa dari tiap kategori level berpikir tingkat tinggi, yaitu satu siswa dengan kategori sangat baik, seorang siswa dengan kategori baik, seorang siswa dengan kategori cukup, dan seorang siswa dengan kategori kurang.

Setelah tes dilaksanakan, maka didapatlah skor masing-masing siswa. Skor tersebut dijumlahkan lalu dianalisis. Langkah untuk menganalsisis data hasil tes tertulis adalah menentukan nilai tes siswa dan menentukan kategori berpikir tingkat tinggi siswa.

Tabel 1. Kategori Kemampuan Berpikir Tingkat Tinggi Siswa

\begin{tabular}{cc}
\hline Nilai Siswa & Kategori Penilaian \\
\hline $81-100$ & Sangat Baik \\
$61-80$ & Baik \\
$41-60$ & Cukup \\
$21-40$ & Kurang \\
$0-20$ & Sangat kurang \\
\cline { 2 - 2 } (Berdasarkan International Center for the Assesment of Higher Order Thinking)
\end{tabular}

Terakhir adalah menentukan persentase kemunculan indikator kemampuan berpikir tingkat tinggi siswa.

Tabel 2. Indikator Penskoran Kemampuan Berpikir Tingkat Tinggi

\begin{tabular}{cc}
\hline Skor & Indikator Penskoran \\
\hline & Indikator 1: Menganalisis \\
\hline 4 & $\begin{array}{c}\text { Mampu memeriksa dan mengurai informasi secara tepat, mampu memformulasikan } \\
\text { masalah,serta memberikan langkah penyelesaian dengan tepat. }\end{array}$ \\
\hline 3 & $\begin{array}{c}\text { Mampu memeriksa dan mengurai informasi secara tepat, mampu memformulasikan } \\
\text { masalah, dan memberikan langkah penyelesaian dengan hampir tepat atau terdapat } \\
\text { sedikit kekeliruan dalam menjawab soal. }\end{array}$ \\
\hline & $\begin{array}{c}\text { Mampu memeriksa dan mengurai informasi secara tepat, mampu memformulasikan } \\
\text { masalah, namun masih terdapat kesalahan dalam langkah penyelesaian dan jawaban } \\
\text { akhir. }\end{array}$ \\
\hline \multirow{3}{*}{$\begin{array}{c}\text { Belum mampu memeriksa dan mengurai informasi secara tepat, belum mampu } \\
\text { memformulasikan masalah, sehingga langkah penyelesaian dan jawaban akhir tidak } \\
\text { tepat. }\end{array}$} \\
\hline 0
\end{tabular}




\section{Indikator 2: Mengevaluasi}

\begin{tabular}{|c|c|}
\hline 4 & $\begin{array}{l}\text { Mampu menilai, menyangkal, ataupun mendukung suatu gagasan dan memberikan } \\
\text { alasan yang mampu memperkuat jawaban yang diperoleh dengan tepat. }\end{array}$ \\
\hline 3 & $\begin{array}{l}\text { Mampu memberikan alasan yang mampu memperkuat jawaban yang diperoleh } \\
\text { dengan tepat, namun tidak memberikan keputusan/kesimpulan akhir. }\end{array}$ \\
\hline 2 & $\begin{array}{c}\text { Kurang mampu memberikan alasan yang mampu memperkuat jawaban yang } \\
\text { diperoleh dengan tepat, sehingga belum mampu memberikan keputusan/kesimpulan } \\
\text { akhir dengan tepat. }\end{array}$ \\
\hline 1 & $\begin{array}{l}\text { Tidak mampu memberikan alasan yang mampu memperkuat jawaban yang diperoleh } \\
\text { dengan tepat, namun jawaban sudah hampir mengarah ke penyelesaian yang tepat. }\end{array}$ \\
\hline 0 & $\begin{array}{l}\text { Tidak mampu menilai, menyangkal, ataupun mendukung suatu gagasan dan } \\
\text { memberikan alasan yang mampu memperkuat jawaban yang diperoleh sama sekali. }\end{array}$ \\
\hline & Indikator 3: Mengkreasi \\
\hline 4 & $\begin{array}{c}\text { Mampu merancang suatu cara untuk menyelesaikan masalah atau memadukan } \\
\text { informasi menjadi strategi yang tepat. }\end{array}$ \\
\hline 3 & $\begin{array}{c}\text { Mampu merancang suatu cara untuk menyelesaikan masalah atau memadukan } \\
\text { informasi menjadi strategi dengan hampir tepat atau masih terdapat sedikit kesalahan } \\
\text { dalam menuliskan jawaban. }\end{array}$ \\
\hline 2 & $\begin{array}{l}\text { Mampu merancang suatu cara untuk menyelesaikan masalah namun belum mampu } \\
\text { memadukan informasi menjadi strategi yang tepat. }\end{array}$ \\
\hline 1 & $\begin{array}{l}\text { Belum mampu merancang suatu cara untuk menyelesaikan masalah atau memadukan } \\
\text { informasi dengan tepat, namun rancangan jawaban sudah hampir mengarah ke cara } \\
\text { yang tepat. }\end{array}$ \\
\hline 0 & $\begin{array}{c}\text { Tidak mampu merancang suatu cara untuk menyelesaikan masalah atau memadukan } \\
\text { informasi menjadi strategi sama sekali. }\end{array}$ \\
\hline
\end{tabular}

Data yang diperoleh dari hasil wawancara dianalisis dengan langkah mengubah hasil wawancara dari bentuk lisan ke bentuk tulisan dan kemudian menganalisis jawaban hasil wawancara.

\section{Hasil dan Pembahasan}

Penelitian ini dilaksanakan mulai tanggal 2 Februari 2016 hingga 18 Februari 2016 di kelas XI MIPA 1 SMA Negeri 18 Palembang. Penelitian dilaksanakan sebanyak 4 pertemuan $(8$ jam pelajaran) dengan tiga pertemuan untuk kegiatan pembelajaran dan satu pertemuan terakhir untuk tes kemampuan berpikir tingkat tinggi.

Pembelajaran dilaksanakan sesuai langkah-langkah pada pembelajaran berbasis masalah, yaitu orientasi masalah, memahami masalah, menentukan dan menerapkan strategi penyelesaian, dan meninjau ulang proses dan hasil.

Data mengenai kemampuan berpikir tingkat tinggi siswa diperoleh dari hasil tes dengan menggunakan tipe soal berpikir tingkat tinggi. Tes dilaksanakan pada pertemuan keempat atau pertemuan terakhir. Tes dikerjakan oleh siswa secara individu. Penskoran yang dilakukan adalah sesuai dengan rubrik penskoran yang telah dibuat. Masing-masing indikator terdiri atas satu deskriptor. Skor maksimal per descriptor adalah empat dan skor minimumnya adalah nol. Soal pertama terdiri atas dua pertanyaan. Pertanyaan pertama mengacu pada indikator kedua dan pertanyaan yang kedua mengacu pada indikator ketiga. Skor maksimal untuk soal pertama adalah delapan. Soal kedua juga terdiri atas dua pertanyaan. Pertanyaan pertama mengacu pada indikator kedua dan pertanyaan yang kedua 
mengacu pada indikator ketiga. Skor maksimal untuk soal kedua adalah delapan. Soal ketiga terdiri atas satu pertanyaan dan mengacu pada indikator pertama, sehingga skor maksimalnya adalah empat. Total skor maksimal seluruh soal adalah 20 .

Setelah semua jawaban siswa diperiksa dan diberikan skor sesuai rubrik penskoran, maka langkah selanjutnya adalah menjumlahkan skor yang diperoleh dari ketiga soal tersebut lalu dibagi dengan skor maksimal yaitu 20, kemudian dikalikan 100. Setelah diperoleh nilai siswa, selanjutnya nilai tersebut dikelompokkan ke dalam lima kategori kemampuan berpikir tingkat tinggi yang dapat dilihat pada tabel berikut.

Tabel 3. Nilai Kemampuan Berpikir Tingkat Tinggi

\begin{tabular}{cccc}
\hline Nilai & Kategori & Frekuensi & Persentase (\%) \\
\hline $81-100$ & Sangat baik & 5 & 16,667 \\
\hline $61-80$ & Baik & 8 & 26,667 \\
\hline $41-60$ & Cukup & 9 & 30 \\
\hline $21-40$ & Kurang & 8 & 26,667 \\
\hline $0-20$ & Sangat Kurang & 0 & 0 \\
\hline & JUMLAH & $\mathbf{3 0}$ & $\mathbf{1 0 0}$ \\
\hline
\end{tabular}

Dari tabel 4.3 dapat dilihat bahwa frekuensi terbanyak adalah siswa dengan kategori kemampuan berpikir tingkat tinggi cukup. Kemudian, untuk melihat persentase kemunculan indikator kemampuan berpikir tingkat tinggi dari jawaban siswa terhadap soal tes dapat dilihat pada tabel 4.4 di bawah ini.

Tabel 4. Persentase Kemunculan Indikator Kemampuan Berpikir Tingkat Tinggi Siswa

\begin{tabular}{lc}
\hline \multicolumn{1}{c}{ Indikator } & Persentase Kemunculan (\%) \\
\hline Menganalisis Permasalahan & 72,500 \\
\hline Mengevaluasi Gagasan & 70,000 \\
\hline Mengkreasi Penyelesaian & 35,417 \\
\hline
\end{tabular}

Penelitian tentang kemampuan berpikir tingkat tinggi siswa kelas XI bertujuan untuk mengetahui kemampuan berpikir tingkat tinggi siswa kelas XI di SMA Negeri 18 Palembang yang ditunjukkan melalui soal tes yang diberikan.

Pembelajaran dilaksanakan sesuai langkah-langkah pembelajaran matematika berbasis masalah, yaitu: orientasi masalah, memahami masalah, menentukan strategi penyelesaian, dan meninjau ulang proses dan hasil. Selama proses pembelajaran berlangsung, guru menggunakan lembar kerja peserta didik (LKPD) untuk mengefektifkan proses pembelajaran. LKPD yang digunakan telah didesain dan disesuaikan dengan langkahlangkah pada pembelajaran berbasis masalah. Saat pembelajaran, siswa diberikan masalah, lalu mereka bekerjasama dalam kelompoknya, menyelesaikan permasalahan yang diberikan, kemudian mempresentasikan penyelesaian atau solusi yang diperoleh. Siswa terdorong untuk berpikir kritis saat menyelesaikan masalah, aktif 
dalam berdiskusi, dan mengemukakan pendapat pada teman maupun guru. Hal ini sejalan dengan penelitian Roh (2003).

Hasil tes yang telah diperoleh merupakan tes yang dilaksanakan setelah siswa melaksanakan pembelajaran berbasis masalah. Saat pembelajaran, siswa secara tidak langsung telah menggunakan kemampuan berpikir tingkat tingginya dalam menyelesaikan permasalahan. Hal ini sejalan dengan pendapat Ibrahim dan Nur (2011).

Selama proses pembelajaran berbasis masalah, peneliti berperan sebagai fasilitator yang membimbing siswa jika terdapat kesulitan saat menyelesaikan masalah. Kedua hal ini sejalan dengan pendapat yang dikemukakan oleh Roh (2003) dan Linde (2015).

Pada saat siswa berusaha menyelesaikan permasalahan, siswa juga sedang mengembangkan kemampuan berpikir tingkat tingginya. Langkah-langkah pembelajaran berbasis masalah seperti orientasi masalah, memahami masalah, menentukan dan menerapkan strategi penyelesaian, serta meninjau ulang proses dan hasil akan membuat siswa terlatih dalam berpikir tingkat tinggi. Hal ini sesuai dengan yang diungkapkan Linde (2015) yakni PBM berfokus pada pembelajaran siswa sambil berlatih (hands-on) dibandingkan mengingat (hands-off). Hal tersebut menuntut siswa untuk menggunakan kemampuan berpikir tingkat tinggi yang mengharuskan siswa untuk menganalisis, mengevaluasi, dan juga mengkreasi.

Melalui pembagian kelompok dalam pembelajaran, siswa diharapkan agar dapat berdiskusi dengan temannya. Ketika berdiskusi, siswa dapat menyampaikan ide maupun pendapatnya. Untuk menilai maupun memutuskan apakah ide ataupun pendapat tersebut benar dan masuk akal, siswa berpedoman pada kriteria yang telah ditentukan. Pada tahap ini, kemampuan berpikir tingkat tinggi juga dilatih karena memutuskan/menilai suatu gagasan berdasarkan kriteria merupakan indikator kedua dalam kemampuan berpikir tingkat tinggi yang diungkapkan oleh Krathworl (2002).

Siswa yang mendapatkan nilai sangat baik merupakan siswa yang terlibat aktif dalam kegiatan PBM. Mereka aktif dalam menyampaikan idenya saat diskusi serta fokus saat mengerjakan LKPD. Pada saat guru berkeliling kelas untuk memantau pekerjaan siswa dan memberikan pertanyaan, siswa berinisial CAT mampu menjawab dan memberikan alasan yang tepat. Namun, CAT masih lemah dalam mengkreasi penyelesaian. Ini terlihat saat guru menanyakan siswa mengenai pertanyaan yang menuntut siswa untuk mengkreasi jawabannya sendiri. Siswa berinisial CAT terlihat bingung saat akan menjawab, sehingga NA yang merupakan teman sekelompoknya yang memberikan jawaban dan alasan yang tepat ketika mengkreasi penyelesaian. Pada tahap ini, terlihat bahwa kerja sama dalam kelompok sangat dibutuhkan. Namun, hal ini terkadang membuat siswa menjadi terlalu bergantung pada temannya. Hal ini senada dengan pendapat Albanese dan Mitchell (1993) yang mengatakan bahwa dalam PBM terdapat kemungkinan siswa akan menjadi terlalu bergantung pada kelompok diskusi, sehingga siswa dapat kekurangan kenyamanan dan keterampilannya untuk bekerja sendiri saat menyelesaikan permasalahan.

Berdasarkan pengamatan peneliti selama pembelajaran, hampir semua siswa yang terkategori kurang dalam kemampuan berpikir tingkat tinggi adalah siswa yang kurang siap dalam belajar. Hal ini terlihat dari kurangnya inisiatif siswa saat pembelajaran, yaitu mengobrol dan bermain-main. Selain itu, siswa tersebut juga kurang gigih dalam menyelesaikan permasalahan. Hal ini mendukung penelitian Novianti (2014) mengenai analisis kemampuan berpikir tingkat tinggi siswa.

Ketidakmampuan siswa dalam mengevaluasi dan mengkreasi penyelesaian ini menyebabkan pembelajaran berbasis masalah tidak terlalu membantu siswa tersebut untuk berpikir tingkat tinggi. Ini dikarenakan dalam 
pelaksanaan PBM, siswa diharapkan mampu mengevaluasi jawaban melalui tinjauan ulang pada proses dan hasil serta dapat memberikan jawaban evaluasi beserta buktinya. Sedangkan, dalam pembelajaran di kelas, siswa yang terkategori kurang tersebut masih belum serius dalam belajar sehingga belum mampu mengevaluasi dan mengkreasi penyelesaian. PBM mengharuskan siswa untuk aktif diskusi, bekerjasama, dan memiliki kemauan belajar mandiri (Roh, 2003).

Roh (2003) mengatakan bahwa pada penelitian tentang penerapan PBM masih terdapat beberapa diantaranya yang belum efektif, sehingga belum berhasil meningkatkan kemampuan berpikir tingkat siswa. Faktor utamanya adalah kesulitan siswa dalam bekerjasama dan kemauan untuk belajar mandiri (Ibrahim, 2015).

Kemunculan indikator menganalisis permasalahan terlihat dari penyelesaian yang ditulis siswa, yaitu mampu mengurai informasi, menggunakan konsep, serta langkah penyelesaian yang tepat. Apabila analisis permasalahan yang dilakukan benar, penyelesaian yang ditulis mengarah pada penyelesaian yang dimaksud pada soal, dan langkah penyelesaian dilakukan hingga selesai, maka siswa tersebut dapat dikatakan mampu menganalisis permasalahan. Hampir seluruh siswa telah mampu menuliskan langkah penyelesaian dengan arah yang sesuai pada maksud soal.

Kemunculan indikator mengevaluasi lebih rendah dibandingkan indikator menganalisis. Ini disebabkan karena tidak semua siswa dapat memutuskan, menilai, mendukung, menyangkal ataupun menuliskan kesimpulan dengan tepat. Mengevaluasi dapat dilakukan apabila siswa mampu menganalisis permasalahan dengan tepat, memahami maksud pertanyaan dengan benar, serta memberikan alasan/bukti yang tepat. Sehingga, jawaban yang dituliskan akan menjawab pertanyaan yang dimaksud.

Indikator mengkreasi penyelesaian memiliki persentase terendah yaitu sebesar $35,417 \%$. Hal ini disebabkan karena mengkreasi penyelesaian adalah level tertinggi dalam kemampuan berpikir tingkat tinggi. Mengkreasi penyelesaian dapat dilakukan apabila siswa mampu menganalisis permasalahan dengan tepat, menentukan ide awal dengan tepat, serta memberikan bukti/alasan yang tepat.

Dari hasil wawancara dengan keempat siswa subjek wawancara, pembelajaran yang telah dilaksanakan pada pertemuan pertama hingga ketiga telah membantu mereka dalam menyelesaikan soal. Mereka dapat menggunakan langkah-langkah pada saat pembelajaran ketika menjawab soal tes. Hal ini juga sejalan dengan pendapat Ibrahim dan Nur (2011).

Pada pelaksanaan pembelajaran berbasis masalah dalam penelitian ini, peneliti memiliki beberapa keterbatasan/ kelemahan. Ada beberapa siswa yang pada dasarnya kurang memiliki minat dalam menyelesaikan masalah, sehingga mereka merasa enggan untuk bekerjasama dalam menyelesaikan masalah. Selain itu, beberapa siswa juga terlalu bergantung pada teman sekelompoknya yang menurutnya lebih pandai, sehingga beberapa siswa cenderung malas dalam mengemukakan pendapatnya. Kedua hal ini sejalan dengan teori dari Sanjaya (2012) dan Ibrahim (2015) mengenai kelemahan pelaksanaan pembelajaran berbasis masalah.

\section{Penutup}

Berdasarkan hasil penelitian di kelas XI MIPA 1 SMA Negeri 18 Palembang, diperoleh hasil bahwa kemampuan berpikir tingkat tinggi siswa pada pembelajaran matematika berbasis masalah adalah terkategori cukup, dengan rincian persentase sebagai berikut: persentase siswa yang memiliki kemampuan berpikir tingkat tinggi dengan kategori sangat baik adalah 16,667\%. Selanjutnya, 26,667\% memiliki kemampuan berpikir tingkat tinggi dengan kategori baik; $30,000 \%$ memiliki kemampuan berpikir tingkat tinggi terkategori cukup; $26,667 \%$ memiliki kemampuan berpikir tingkat tinggi terkategori kurang; dan tidak ada yang memiliki kemampuan berpikir tingkat tinggi dengan kategori sangat kurang. Indikator menganalisis memiliki 
persentase kemunculan tertinggi yaitu sebesar $72,500 \%$. Kemudian, kemunculan pada indikator mengevaluasi adalah sebesar $70,000 \%$, dan indikator dengan persentase kemunculan terendah adalah mengkreasi yaitu sebesar $35,417 \%$.

Dari hasil penelitian yang diperoleh, maka peneliti menyarankan:

1. Bagi guru, saat pembelajaran matematika berbasis masalah agar dapat lebih menekankan proses meninjau ulang proses dan hasil agar kemampuan berpikir tingkat tinggi siswa pada indikator mengkreasi dapat meningkat lebih baik lagi, membiasakan siswa dalam menyelesaikan masalah, menggunakan atau membuat sendiri bahan ajar yang dapat melatih kemampuan berpikir tingkat tinggi siswa, serta lebih sering membuat/menggunakan, memberikan, dan membahas soal-soal bertipe tingkat tinggi.

2. Bagi siswa, agar dapat mengembangkan kemampuan berpikir tingkat tinggi dengan sering berlatih mengerjakan soal-soal bertipe tingkat tinggi, khususnya soal dengan indikator mengevaluasi dan mengkreasi.

3. Bagi sekolah, agar dapat memfasilitasi guru dalam membuat atau menggunakan buku/sumber belajar yang dapat mengasah kemampuan berpikir tingkat tinggi siswa.

\section{Referensi}

Amalia, R., 2013. Penerapan Model Pembelajaran Pembuktian Untuk Meningkatkan Kemampuan Berpikir Matematis Tingkat Tinggi Siswa SMA. Jurnal Pendidikan Matematika Universitas Pendidikan Indonesia.

Antara., 2013. Kualitas SDM di Indonesia masihrendah.http://www.antaranews.com/berita/ 403069/bkkbn-kualitas-sdm-indonesiamasih-rendah. Diakses pada 15 April 2014 Ibrahim, M., dan Nur M., 2011. Pengajaran Berdasarkan Masalah. Surabaya: Unesa University Press.

Khotimah, K., 2011. Pengembangan Bahan Ajar Matematika Mengacu pada Pembelajaran
Berbasis Masalah bagi Siswa Kelas VII SMPN 1 Rambang Dangku. Tesis, Palembang: FKIP Unsri.

Krathwohl,, 2002. A revision of Bloom's Taxonomy: an overview. Theory Into Practice, 41 (4): 1-8.

Lewy., Zulkardi., dan Aisyah N., 2009. Pengembangan Soal Untuk Mengukur Kemampuan Berpikir Tingkat Tinggi Pokok Bahasan Barisan dan Deret Bilangan di Kelas IX Akselerasi SMP Xaverius Maria Palembang. Jurnal Pendidikan Matematika, (Volume 3 No.2 Desember 2009); 4-6.

Linde, S., 2016a. Problem-Based Learning Activities in Math, Chapter 8 Lesson 46. http://study.com/academy/lesson/problembased-learning-activities-in-math.html.

Diakses pada 27 Februari 2016.

2016b., Problem-Based Learning: Examples, Theory \& Definition Chapter 8 Lesson 80 http://study.com/academy/lesson /problem-based-learning-activities-

imath.html. Diakses pada 27 Februari 2016.

Luthfiana., 2013. Penerapan Strategi Brain Based Learning yang Dapat Meningkatkan Keterampilan Berpikir Tingkat Tinggi. Jurnal Pendidikan Matematika Universitas Negeri Malang.

Novianti, D., 2014. Analisis Kemampuan Berpikir Tingkat Tinggi Siswa dengan Gaya belajar Investigatif dalam Pemecahan Masalah Matematika Kelas VII di SMPN 10 Kota Jambi. Jurnal Pendidikan Matematika Universitas Jambi

Permanasari, V., 2013. Efektivitas Pendekatan Pembelajaran Open-Ended terhadap Kemampuan Berpikir Matematis Siswa pada Materi Trigonometri Ditinjau dari Kreativitas Belajar Matematika Siswa. Jurnal Pendidikan Matematika Solusi, 1(1): 1-7.

Raudenbush, Stephen W, dkk., 1992. Teaching for Higher-Order Thinking in Secondary 
JURNAL GANTANG Pendidikan Matematika FKIP - UMRAH

Vol. 1 No. 1, Agustus 2016, p-ISSN. 2503-0671, e-ISSN. 2548-5547

Schools: Effects of Curriculum, Teacher Preparation, and School Organization. Office of Educational Research and Improvement (ED). Washington, DC: Center for Research on the Context of Secondary School Teaching.

Roh, K., 2003. Problem-Based Learning in Mathematics. ERIC Clearinghouse for Science Mathematics and Environmental Education.http://www.eric.ed.gov/PDFS/ ED482725.pdf . Diakses pada 28 Februari 2016.

Sanjaya, W., 2014. Strategi Pembelajaran: Berorientasi Standar Proses Pendidikan. Jakarta: Kencana

Shadiq, F., 2014. Pembelajaran Matematika: Cara Meningkatkan Kemampuan Berpikir Siswa. Graha Ilmu: Yogyakarta. Sastrawati, E., 2011. Problem BasedLearning, Strategi Metakognisi, dan Keterampilan Berpikir Tingkat Tinggi Siswa. Jurnal Tekno-Pedagogi ISSN 2088-205X, 1(2):3-7.

Vui, T., 2001. Enhancing Classroom Communication to Develop Students Mathematical Thinking. (http://www.criced.tsukuba.ac.jp/math/ap ec/apec2008/papers/PDF/21.Tran_Vui_V ietnam.pdf). Diakses tanggal 12 April 2015.

Ulfa, W., dkk., 2013. Pengaruh StrategiPembelajaran Berbasis Masalah Terhadap Kemampuan Berpikir

Tingkat Tinggii (Menganalisis,Mengevaluasi, Mencipta) dan Keterampilan Proses Sains Mahasiswa STIPAP LPP Medan, Jurnal UNIMED: 1-5. 